\title{
Integrated Model of Destination Competitiveness
}

\author{
Armenski TanjaA*, Marković Vladimir, Davidović NemanjaA, Jovanović Tamara ${ }^{\mathrm{A}}$ \\ Received: December 2010 | Revised: April 2011 | Accepted: May 2011
}

\begin{abstract}
The aim of this paper is to determine the weakest point of Serbian destination competitiveness as a tourist destination in comparation with its main competitors. The paper is organised as follows. The short introduction of the previous research on the destination competitiveness is followed by description of the Integrated model of destination competitiveness [Dwyer et al, 2003] that was used as the main reference framework. Section three is devoted to the description of the previous studies on competitiveness of Serbian tourism, while section four outlines the statistical methodology employed in this study and presents and interprets the empirical results. The results showed that Serbia is more competitive in its natural, cultural and created resources than in destination management while, according to the Integrated model, Serbia is less competitive in demand conditions that refer to the image and awareness of the destination itself.
\end{abstract}

Keywords: integrated model, destination competitiveness; tourism, Serbia.

\section{Introduction}

The success of tourism destinations in world markets is influenced by their relative competitiveness. A competitive advantage can be achieved if the overall appeal of the destination is superior to that of an alternative destination to potential visitors (Dwyer, Kim, 2003). However, it must be highlighted that the competitiveness of the tourism destination is not defined by the set of rigid natural, cultural, artistic or environmental resources, but it is seen as an overall appeal of the destination (Cracolici, Nijkamp, 2009). Consequently, tourism will achieve a favourable position on the tourism market if destination recourses are managed properly and if a destination is capable of gaining and maintaining competitive advantages (Teece et al, 1997).

In order to achieve proper matches between tourism resources and management strategies, it is necessary for the industry and government to determine and understand the weakest and strongest points of their country's competitiveness, thus we have applied the Integrated model of destination competitiveness on Serbia as a tourism destination.
Based on the Integrated model, a set of indicators was developed to measure the competitiveness of any given destination. The selected set of 85 indicators was based on discussions in workshops held in Korea and Australia in 20or. Participants at these workshops identified the important indicators of destination competitiveness falling under the main elements of the destination competitiveness model (Kim, Dwyer, 2003). This model was applied to Australia and Korea by Dwyer, Livaic and Mellor in 2003 and later in Slovenia by Omerzel- Gomezelj and Mihalic (2008), who had applied the same model in 2004.

The underlying idea of this paper is that competitive position of a destination on the tourism market depends on the choice and quality of the management of destination resources. As a result, one main hypothesis was created: the weakest point of Serbian destination competitiveness is destination management. Additionally, three sub-hypotheses were established. The first subhypothesis claims that Serbia is more competitive in the attractiveness of its created, inherited and supporting resources than in its destination man-

\footnotetext{
A Faculty of Science, Department of Geography, Tourism and Hotel Management, University of Novi Sad, Trg Dositeja Obradovica 3, 21000 Novi Sad, Serbia

* Tanja Armenski, e-mail: tanja.armenski@dgt.uns.ac.rs
} 
agement and that among the resources inherited resources are more competitive than created resources and at the same time are more competitive than supporting resources.

The second sub-hypothesis was created based on the previous research finding on Serbian competitiveness and claims that destination conditions, in the destination are more competitive comparing to the destination management. The destination condition according to the applied model, comprise the three main elements of tourism demand: awareness of destination on the international tourism market, perception of destination and tourism preferences. The third sub-hypothesis tests the relation between situation and demand condition comparing to the destination management.

The paper is organised as follows. In section two, we describe the rationale and context of our study, where we use the Integrated model of competitiveness (Dwyer et al, 2003) as our main reference framework. Section three is devoted to the description of the previous studies on competitiveness of Serbian tourism, while section four outlines the statistical methodology employed in this study and presents and interprets the empirical results. Section five introduces some concluding remarks.

\section{Literature review}

Destination competitiveness is the ability of one country to create additional values and thus increase the national wealth by managing assets and processes, attractiveness, aggressiveness and proximity and by integrating these relationships within an economic and social model that takes into account a destination's natural capital and its preservation for future generations (Ritchie, Crouch, 2003). A large number of authors have given their contribution to the understanding and practical research of competitiveness of tourist destinations (De Keyser, Vanhove, I994; Evans, Johnson, I995; Pearce, 1997; Hassan, 2000; Kozak, 200I; Mihalic, 2000; Ritchie, Crouch, I993; Thomas, Long, 2000; Alavi, Yasin, 2000; Enright, Newton, 2004; Ruhanen, 2007; Cracolici, Nijkamp, 2009).

However, how complex the term competitiveness is becomes apparent only when we try to define and measure competitiveness. Thus, there are many models created in an attempt to measure competitiveness as a unique phenomenon. Models differ according to the defined factors that determine competitiveness and their grouping. However, the authors have decided to use the Integrated model of competitiveness (Kim, Dwyer, 2003) which was developed from a Conceptual model of competitiveness (Ritchie and Crouch, I993).
The most detailed work undertaken by tourism researchers on overall tourism competitiveness is that of Ritchie and Crouch (1993, 2000) and Crouch and Ritchie (1994, I995, I999). They examined the applicability to tourism destinations of competitiveness research and models in other contexts spanning companies and products, national industries, and national economies as well as competitiveness related to service industries. Crouch and Ritchie claim that, in absolute terms, the most competitive destination is one which brings greatest success; that is, the greatest wellbeing for its residents on a sustainable basis. Thus the most competitive destination is that which most effectively creates sustainable well-being for its residents. In 2003 tourism competitiveness researcher, Crouch and Ritchie tested and presented the new improved version of their competitiveness model: the Conceptual Model of Destination Competitiveness.

Ritchie and Crouch stated that competitiveness is illusory without sustainability. To be competitive, a destination's development for tourism must be sustainable, not only economically and ecologically, but socially, culturally and politically as well (2000). Major elements of the model are: destination policy, planning and development, destination management, core resources and attractors and supporting factors and resources.

Some of the variables identified by Ritchie and Crouch have been included in the so-called Integrated model by Dwyer, Livaic and Mellor (2003). A model of destination competitiveness has been suggested by the authors. This model is displayed schematically in Figure I. The model brings together the main elements of national and firm competitiveness as proposed in related literature (Cho, I998; Moon, Peery, I995; Narashima, 2000; Porter 1990; Waheeduzzan, Ryans, I996) and the main elements of destination competitiveness as proposed by various tourism researchers (Crouch, Ritchie, I995, I999; Dwyer et al, I999, 2000a, 2000b, 2002; Hassan, 2000; Ritchie, Crouch, 2000)

Integrated model retains much of CrouchRitchies model, but differs from it in some important details (Dwyer et al, 20or). It seeks a more realistic picture of the connections between different parts of the model opposite to Crouch and Ritchie model (I999). Their model is linear, dependence between different groups of factors are shown in only one direction. Integrated model assumes mutual dependence between the individual elements. While Crouch-Ritchie models sources are considered as one group factors, the Integrated model explicitly separates the primary sources (especially distinguishes natural from cultural and historical) from the expanded. 
Integrated model underlines the importance of demand factors. Awareness of alternative tourist destinations, their tourism offers and tourists perception of differences between destinations are critical factors of a tourist flow. Destination must develop such tourism products, that will provoke tourism demand. Crouch-Ritchies model unduly neglected competition factors on the demand side. It focuses only on the supply side and the provides an incomplete picture of the competitiveness of tourist destinations (Omerzel- Gomezelj, Michalic, 2008).

Integrated model includes a tourist policy, planning and destinations development (Crouch and Ritchie are classified in a separate category) as group factors under the common name of the management. The Integrative model classifies the determinants of destination competitiveness under several main headings. It's main, so called competitiveness determinants are inherited resources, created resources, supporting factors and resources, destination management, situational conditions and demand conditions. The model has been empirically tested in Korea and Australia in 200I, in Slovenia in 2004 (Omerzel- Gomezelj, Michalic, 2008) while in 2009 the methodology was adopted and applied to Serbia in 2009.

\section{The Competitiveness of Serbian Tourism}

Serbia is a country that covers an area of 88,36 I $\mathrm{km}^{2}$, with a population of about 7 milion (excl. Kosovo). The Serbian climate varies between continental climates in the north, to a more Adriatic climate in the south. South and South-west Serbia is subjected to Mediterranean influences. However, the Dinaric Alps and other mountain ranges contribute to the cooling down of most of the warm air masses. Dinaric Alps of Serbia follow the flow of the Drina River, overlooking Dinaric peaks on the opposite banks in Bosnia and Herzegovina.

Due to political instability and wars that took place in the region, from the dissolution of Socialist Yugoslavia to the Kosovo war (I99I-I999), Serbia has since registered a slow recovery and the numbers of domestic and foreign tourists are still below the best results seen in the period between I982 through I99I (Djuric, 200I; Simic, I997; Weber, I989, John, I985, Mikic, I988; Bakic, I988).

After 2006, with the dissolution of "Serbia and Montenegro, Serbia became an independent Republic. After the independence and the loss of Adriatic Sea, Serbia has developed urban, business, rural, mountain and spa tourism.

A foreign tourism inbound is an important item and indicator of tourism prosperity. In the period between the $200 \mathrm{I}$ and 2010 years, there has been a steady rise in the number of foreign tourists (Table I).

Table 1. Foreign tourists arrivals and overnight stays in the Republic of Serbia in the period from 2001 to 2010.

\begin{tabular}{|r|r|r|}
\hline Year & \multicolumn{1}{|c|}{ Arrivals } & \multicolumn{1}{c|}{ Nights } \\
\hline 2001. & 446.373 & 908.982 \\
\hline 2002. & 503.038 & 1.044 .566 \\
\hline 2003. & 509.100 & 1.076 .156 \\
\hline 2004. & 539.293 & 1.082 .994 \\
\hline 2005. & 578.272 & 1.204 .301 \\
\hline 2006. & 585.559 & 1.200 .709 \\
\hline 2007. & 696.045 & 1.475 .675 \\
\hline 2008. & 646.494 & 1.398 .887 \\
\hline 2009. & 645.022 & 1.469 .102 \\
\hline 2010. & 682.681 & 1.452 .156 \\
\hline
\end{tabular}

Source: Statistical office of the Republic of Serbia, 2010.

In order to improve foreign inbound and its competitiveness in the region, the Republic of Serbia has carried out the first study on its competitiveness in 2005 as a part of the Strategy of tourism development (Horwath Consulting Zagreb, Economic Faculty Belgrade, 2005). In order to measure the competitiveness of Serbia, I2 different parameters of competitiveness were taken into consideration. However, the selected attributes do not appear to be based on any model of competitiveness. According to the mentioned study, the following elements were highly rated: social elements, human resources, restaurants, and natural and cultural resources. The worst rated tourist elements were river tourism, tourist signalisation, information and presentations, travel laws and legislative basis, the availability and transportation and infrastructure.

Moreover, the political competitiveness does not give sufficiently positive contribution to the shaping of an adequate competitive position that Serbia has on the international tourist market (Popesku, 2008). After the period between I989 and 2000, Serbia is still unable to reach the level of political stability that is required to achieve the desired competitive position. Due to the negative political developments, Serbia has acquired a negative image as a tourist destination (Howard, Allen, 2008). Therefore, tourism should be focused on creating a positive image and strive to increase the volume of the tourist traffic through a greater supply of qualitative and quantitative variables - the better development of different types of tourism through the selective affirmation of natural, anthropogenic and cultural content, and better management of these resources (Jovicic, 2008; Besermenji et al, 2009; Stetic, Simicevic, 2008; Stojanovic, Stamenkovic, 2008; Ivkov-Dzigurski 
et al, 2008; Ivkov et al, 2007; Dragin et al, 2007; Besermenji et al, 2010).

\section{Research Methodology}

In order to carry out the research on competitiveness of Serbia, a research model was adopted from the authors Omerzel- Gomezelj, Mihalic (2008) who have applied the same Intergrated competitiveness model in Slovenia. From the perspective of our study, this model was the most relevant. It brings together the main elements of destination competitiveness, it provides a realistic display of linkages between various elements, the useful distinction between inherited and created resources, and the category management -an important issue of our research - which includes all relevant determinants that shape and influence a destination.

Some of the connections developed by Dwyer et al (2003) have been retained but part of the original model, which linked competitive determinants to indicators, and economic prosperity were eliminated (Figure I). Economic prosperity of the destination is not taken into study because it refers to a long-term maintenance of competitive- ness on the international tourist market and on that basis achieving economic prosperity of a destination. However, since the goal of this study was to identify the weakest and strongest points of a country's tourism industry at the moment and not to follow long term effect of competitive position on the tourism market, economic prosperity of the destination was eliminated.

Inherited (INHRES), created (CRERES) and supporting Resources (SUPRES) encompass the various characteristics of a destination that make it attractive to visit (Omerzel- Gomezelj, Mihalic, 2008).

Destination management (DESTMNGM) covers factors that enhance the attractiveness of the inherited and created resources, strengthen the quality of the supporting factors and those which best adapt to the situational conditions (Crouch, Ritchie, I999).

Although in understanding the elements of destination management the Integrated model follows the Ritchie and Crouch model (Crouch, Ritchie, I999), the Integrated model also developed a separate box on demand conditions. These (DEMANDCON) comprise the three main elements of tourism demand: awareness, perception

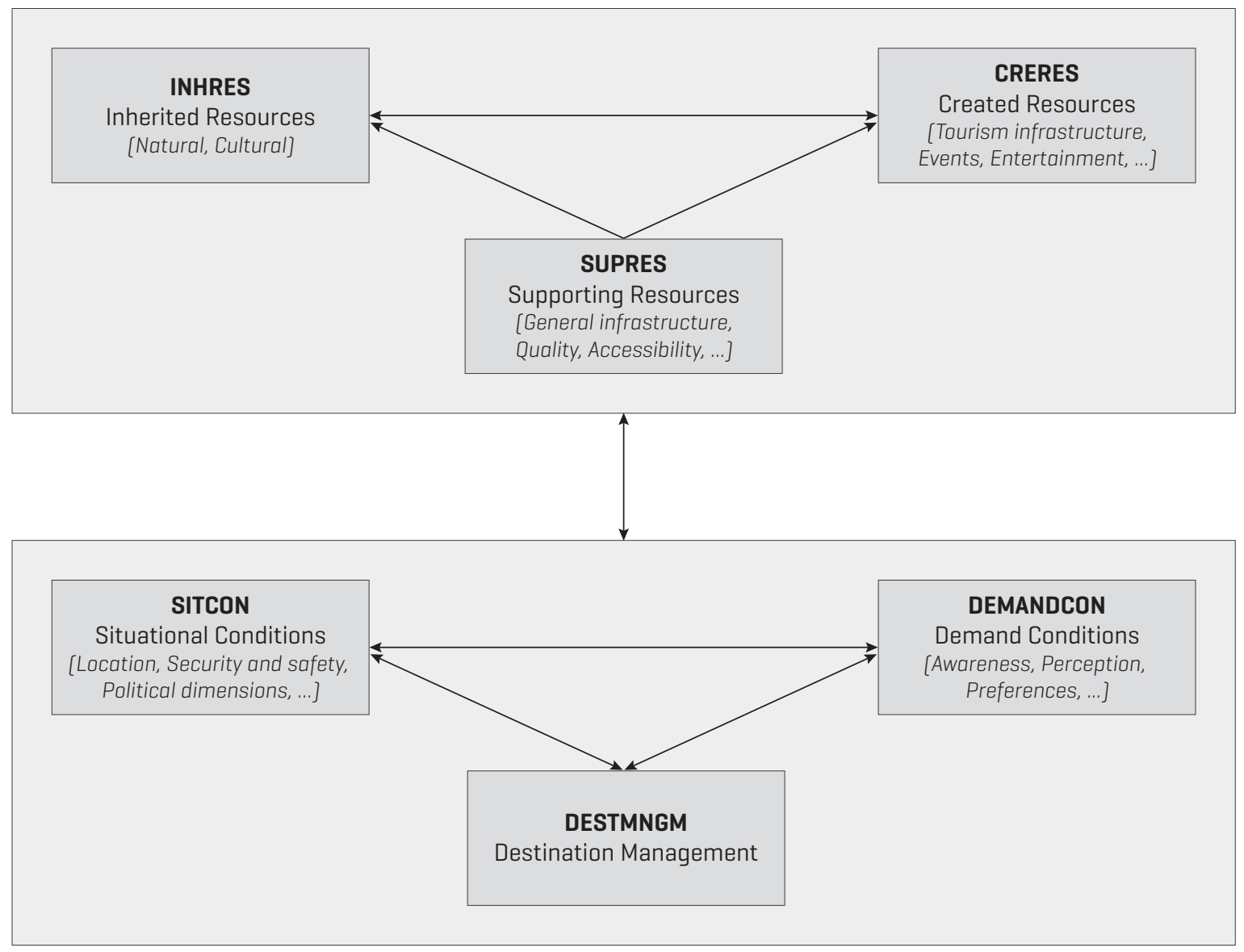

Figure 1. Integrated model of destination competitiveness - the main determinants Sources: adopted from Dwyer et al, 2003. 
and preferences (Kim, Dwyer, 2003). The factors of situational conditions (SITCOM) can moderate, modify or even mitigate a destination's competitiveness. There seem to be many types of such factors, e.g. location, micro and macro environment, security and safety, and price competitiveness (Omerzel- Gomezelj and Mihalic, 2008).

The study was conducted during summer and autumn 2009. Data were gathered by a questionnaire. Based on the Integrated model (Dwyer et al, 2003), 85 competitive indicators were created in the form of 85 statements. The statements were grouped into six categories of the Integrated model of destination competitiveness: inherited (INHRES), created (CRERES) and supporting resources (SUPRES), destination management (DESTMNGM), situational conditions (SITCON), demand conditions (DEMANCON).

The authors decided that research should be conducted among experts and practitioners and not among tourists, because it is considered that tourists are capable of evaluating those components of destination attractiveness among the services they consume. However, they are less likely to know about, and hence be able to evaluate, those factors that underlie and influence the competitive production of those services, especially because of their status as visitors (Enright, Newton, 2004).

Therefore, the research sample was made out of tourism stakeholders on the supply side, namely the tourism industry, government, schools of tourism and postgraduate students of tourism management with some work experience. The use of tourism experts as tourism stakeholders hase some benefits and advantages. Their knowledge about the entire portfolio of destination competitive resources can help to discover the tourist destination more appropriately.

When comparing destinations, it is necessary to establish which destinations (or countries) represent direct competitors. A specific tourism destination is not competitive or uncompetitive in the abstract, but versus competing destinations and it is important to establish which destinations comprise the competitive set (Kozak, Rimmington, I999). Therefore, respondents were asked to indicate their own group of the most competitive destinations. The majority (90\%) created their own group of the following countries: the neighbouring Hungary, FYR Macedonia, Bosnia and Herzegovina, Montenegro, Croatia, as well as Slovenia. According to the respondents' opinion, the strongest Serbian competitors are surrounding countries which offer similar tourist products due to their historical, cultural and natural similarities. However, given that Serbia is a continental country with no possibility of the development of coastal tourism, it is considered improper to com- pare it to coastal tourist destinations such as Croatia, Montenegro and Slovenia. Consequently, the most competitive are those destinations that have very similar natural characteristics and which have therefore developed the same types of tourism such as city tourism, business tourism, event tourism, spa tourism and rural tourism.

Secondly, respondents were asked to rate each of the 85 competitive indicators on a five-point Likert scale comparing Serbia to, in their opinion, the most competitive destination. The options ranged from I (the competitiveness level in Serbia is well below the same level in the competitive destination) to 5 (the competitiveness level in Serbia is much above the same level in the competitive destination). The competitive indicators are those rated with the mark higher than 3 . The SPSS standard package for personal computers was used for data processing.

\section{Research Findings}

All of I40 questionnaires were obtained. The research sample included $5 \%$ government officials, $22.9 \%$ managers in travel agencies, $9.3 \%$ managers in hospitality sector, I0.7\% tourism academic staff, $7.9 \%$ tourism service managers, $29.9 \%$ postgraduate students of tourism, $14.3 \%$ employees in local tourist organisations. The research sample consisted of $73.6 \%$ of tourism stakeholders who had been employed within the tourism industry for less than Io years, I3.6\% from in to 20 years, IO\% from 2I to 30 years and $2.8 \%$ for more than 30 years. The majority of participants were young, between I9 and 28 years of age (50\%), while $22.9 \%$ of participants were up to 38 years of age. $52.9 \%$ respondents were female and 47.1\% male. The majority $(70.7 \%)$ of participants had completed college or university studies. Sample characteristics are shown in Table 2.

\section{Limitation in the research process}

Given that the majority of respondents had less than Io years of experience in the tourism industry, it was necessary to check their validity to participate in the study and discussed the competitiveness of Serbia as a tourist destination. Regarding their work experience in tourism industry, the respondents were divided into four groups: work experience in tourism industry of less than to years, work experience in tourism industry from II to 20 years, from 2I to 30 years and more than 30 years. In order to examine if respondents` answers differ according to their work experience while measuring the competitive factors analyses of variance One Way Anova was performed (Table 3).

Using One-Way ANOVA method for investigation of significance of mean value differ- 
Table 2. Sample characteristics

\begin{tabular}{|l|r|}
\hline Number of respondents & 140 \\
\hline Age & $50,0 \%$ \\
\hline $19-28$ & $22,9 \%$ \\
\hline $29-38$ & $10,0 \%$ \\
\hline $39-48$ & $16,4 \%$ \\
\hline $49-58$ & $0,7 \%$ \\
\hline $59-68$ & \\
\hline Work position & $5,0 \%$ \\
\hline Government officials & $22,9 \%$ \\
\hline Tourist agency managers & $10,7 \%$ \\
\hline Tourism school academics & $9,3 \%$ \\
\hline Hospitality sector managers & $7,9 \%$ \\
\hline Tourism service managers & $29,9 \%$ \\
\hline Postgraduate students on tourism courses & $14,3 \%$ \\
\hline Employers in local tourist organisations & \\
\hline Work experience in tourism industry & $73,6 \%$ \\
\hline Linked with tourism industry for less than 10 years & $13,6 \%$ \\
\hline Linked with tourism industry from 11 to 20 years & $10,0 \%$ \\
\hline Linked with tourism industry from 21 to 30 years & $2,9 \%$ \\
\hline Linked with tourism industry more than 30 years & \\
\hline Gender & \\
\hline Female & \\
\hline Male & \\
\hline & \\
\hline
\end{tabular}

Source: Data obtained by survey research

Table 3. Compare Means One-Way ANOVA

[Dependent List: INHRES, CRERES, SUPRES, DESTMNG, SITCON, DEMANDCON; factor: length of working in the tourism industry]

\begin{tabular}{|c|c|c|c|c|}
\hline & & $\mathrm{df}$ & $\mathrm{F}$ & Sig. \\
\hline \multirow{3}{*}{ INHRES } & Between Groups & 3 & 1,481 & 0,222 \\
\hline & Within Groups & 136 & & \\
\hline & Total & 139 & & \\
\hline \multirow{3}{*}{ CRERES } & Between Groups & 3 & 1,490 & 0,220 \\
\hline & Within Groups & 135 & & \\
\hline & Total & 138 & & \\
\hline \multirow{3}{*}{ SUPRES } & Between Groups & 3 & 1,174 & 0,322 \\
\hline & Within Groups & 136 & & \\
\hline & Total & 139 & & \\
\hline \multirow{3}{*}{ DESTMNG } & Between Groups & 3 & 0,646 & 0,587 \\
\hline & Within Groups & 136 & & \\
\hline & Total & 139 & & \\
\hline \multirow{3}{*}{ SITCON } & Between Groups & 3 & 1,115 & 0,346 \\
\hline & Within Groups & 136 & & \\
\hline & Total & 139 & & \\
\hline \multirow{3}{*}{ DEMANDCON } & Between Groups & 3 & 0,368 & 0,776 \\
\hline & Within Groups & 136 & & \\
\hline & Total & 139 & & \\
\hline
\end{tabular}

Source: Data obtained by survey research ences it may be concluded there are no statistically significant dissimilarities between the factors of competitiveness (INHRES, CRERES, SUPRES, DESTMNG, SITCON, DEMANCON) compared to the length of work experience of respondents in the tourism industry, meaning that all respondents can be taken into research without probability of influencing the research validity.

\section{Competitiveness according to individual competitiveness indicator}

In the following section, competitiveness is analysed according to individual competitiveness indicators, grouped in the six main determinants as it was suggested by the Integrated model. This is followed by an attempt to evaluate the weakest points of Serbian tourism competitiveness.

\section{Inherited resources}

Serbia is, when compared to its competitive destinations, regarded as being more competitive than its competitors in most attributes of the Inherited Resources (Table 4). Interviewees suggested that cleanliness ( $\mathrm{AM}=2, \mathrm{IO} 7 \mathrm{I} ; \mathrm{SD}=\mathrm{I}, 0227$ ) was the most incompetent factor compared to the competitive destinations. Additionally, Serbia as a continental country has less attractive climate for tourists. The highest rating was assigned to the historic sites $(\mathrm{AM}=3,657 \mathrm{I} ; \mathrm{SD}=\mathrm{I}, \mathrm{oor} 9)$, heritage and traditional art.

The smallest standard deviation in this group was assigned to unspoiled nature and flora and fau$n a$, which with a value of $\mathrm{SD}=0.85$ and $\mathrm{SD}=0.89$ indicates quite a high level of agreement between the respondents. The relatively high standard deviation is found in national parks ( $\mathrm{SD}=\mathrm{I}, \mathrm{I} 69 \mathrm{I})$, artistic and architectural features and historic sites, which indicate that the respondents hold different perceptions of these attributes.

Table 4. Mean values [AM] and standard deviations [SD] for individual competitiveness indicators of inherited resources [INHRES]

\begin{tabular}{|l|c|c|}
\hline & Mean & SD \\
\hline Historic sites & 3,6571 & 1,0019 \\
\hline Heritage & 3,5786 & 0,9526 \\
\hline Traditional arts & 3,5214 & 0,9480 \\
\hline Flora and fauna & 3,3643 & 0,8993 \\
\hline Artistic and architec. features & 3,2071 & 1,0695 \\
\hline Unspoiled nature & 3,0143 & 0,8565 \\
\hline National parks & 3,0000 & 1,1691 \\
\hline $\begin{array}{l}\text { Attractiveness of } \\
\text { climate for tourism }\end{array}$ & 2,7357 & 1,0079 \\
\hline Cleanliness & 2,1071 & 1,0227 \\
\hline
\end{tabular}

Source: Data obtained by survey research 


\section{Created resources}

Nightlife (AM=3,7929; $\mathrm{SD}=\mathrm{I}, \mathrm{II} 56)$, variety of different cuisines, special events/festivals, food service facilities, health resorts and spa, winter-based activities and diversity of shopping experience are highly rated created resources. However, more than half of 24 of these indicators are rated rather low. Water- based activities ( $\mathrm{AM}=\mathrm{I}, 8857 ; \mathrm{SD}=\mathrm{I}, 0184)$, visitors' accessibility to natural areas, amusement/ theme parks, airport efficiency/quality and existence of tourism programmes for visitors, tourism guidance, recreation facilities, accommodation, adventure activities, casino, transport efficiency, sport facilities, congress tourism, nature-based activities, entertainment as well as rural tourism are rated low and according to interviewees considered not to be competent (Table 5).

\section{Supporting factors}

Only two out of I2 supporting factors have value higher than 3, thus are rated as being more competitive in comparison to the chosen set of competitive destinations: hospitality ( $\mathrm{AM}=3,3 \mathrm{I} 43$; $\mathrm{SD}=\mathrm{I}, 0532)$ and financial institutions and currency exchange facilities ( $\mathrm{AM}=3, \mathrm{I} 7 \mathrm{I} 4 ; \mathrm{SD}=0,9 \mathrm{I} 3 \mathrm{I})$. Other competitiveness indicator values are not regarded as competitive. Serbia fails to meet visitor needs, especially in the tourism animation $(\mathrm{AM}=2,4000 ; \mathrm{SD}=0,8549)$ and visa requirements as impediment to visitation $(\mathrm{AM}=2,457 \mathrm{I} ; \mathrm{SD}=$ I,3377) (Table 6). Overall, ratings for indicators of Supporting factors were considerably lower than for Inherited resources and Created resources.

\section{Destination management}

According to the applied model, Serbia is less competitive in all indicators of the Inherited model comparing to its competitors. The highest was rated the existence of an adequate tourism educational programme ( $\mathrm{AM}=2,8000 ; \mathrm{SD}=0,9685)$ while the lowest was rated the destination policy regarding social tourism (AM=2,I2I4; $\mathrm{SD}=0,963 \mathrm{I})$. Overall, indicators for the destination management were rated lowest and considered to be below the level of same indicators in competitive destinations (Table 7).

\section{Situational conditions}

Value for money in shopping items ( $\mathrm{AM}=3,0429$; $\mathrm{SD}=0,9125)$ is the only indicator consider to be competitive . According to respondents, value for money in shopping items mainly refers to low prices of food and beverage. Relatively low cost of goods and services could be attractive to tourists and thus make Serbia a favourable tourist destination (Armenski et al, 2009). For a destination to be favoured in the minds of potential visitors, it is necessary to provide more information and better marketing on the international tourist market.
Table 5. Mean values [AM] and standard deviations [SD] for individual competitiveness indicators of created resources [CRERES]

\begin{tabular}{|l|r|l|}
\hline & Mean & \multicolumn{1}{l|}{ SD } \\
\hline Nightlife & 3,7929 & 1,1156 \\
\hline Variety of cuisine & 3,6929 & 0,9360 \\
\hline Special events/festivals & 3,2143 & 1,0373 \\
\hline Food service facilities & 3,2071 & 0,9095 \\
\hline Health resorts, spa & 3,1429 & 1,2441 \\
\hline Winter based activities & 3,0714 & 1,2033 \\
\hline Diversity of shopping experience & 3,0571 & 0,9947 \\
\hline Rural tourism & 2,9786 & 1,1024 \\
\hline Entertainment & 2,9214 & 0,9823 \\
\hline Nature based activities & 2,8571 & 1,1160 \\
\hline Congress tourism & 2,8214 & 1,0746 \\
\hline Community support for special event & 2,8071 & 1,0721 \\
\hline Sport facilities & 2,6714 & 1,0138 \\
\hline Local tourism transportation & 2,6214 & 1,0420 \\
\hline efficiency/quality & 2,6143 & 0,9934 \\
\hline Casino & 2,6143 & 1,0633 \\
\hline Adventure activities & 2,6071 & 1,0505 \\
\hline Accomodation & 2,4748 & 1,0309 \\
\hline Recreation facilities & 2,4643 & 0,9476 \\
\hline Tourism guidance and information & 2,3643 & 0,7975 \\
\hline Existence of tourism programs for visitors & 1,8857 & 1,0184 \\
\hline Airport efficiency/quality & & \\
\hline Amusement/Theme parks & 2,0847 \\
\hline Visitors accessibility to natural areas & 1,0311 \\
\hline Water based activities & 2,3071 & 0,8738 \\
\hline Source: & & \\
\hline
\end{tabular}

Source: Data obtained by survey research

Table 6. Mean values [AM] and standard deviations [SD] for individual competitiveness indicators of supporting resources [SUPRER]

\begin{tabular}{|l|r|r|}
\hline & \multicolumn{1}{|c|}{ Mean } & \multicolumn{1}{c|}{ SD } \\
\hline Hospitality of residents towards tourists & 3,3143 & 1,0532 \\
\hline $\begin{array}{l}\text { Financial institutions and currency } \\
\text { exchange- facilities }\end{array}$ & 3,1714 & 0,9131 \\
\hline Telecommunication system for tourists & 2,9929 & 0,8353 \\
\hline $\begin{array}{l}\text { Communitation and trust between } \\
\text { tourists and residents }\end{array}$ & 2,7786 & 1,0800 \\
\hline $\begin{array}{l}\text { Destination links with major origin } \\
\text { markets }\end{array}$ & 2,6857 & 0,9298 \\
\hline Attitudes of custom/immigration officials & 2,6500 & 0,9739 \\
\hline Quality of tourism sector & 2,6143 & 0,9490 \\
\hline Health/medical facilities to serve tourists & 2,5857 & 0,9890 \\
\hline Efficiency of customs/imigration & 2,5643 & 0,9687 \\
\hline Accessibility of destination & 2,5500 & 0,9470 \\
\hline $\begin{array}{l}\text { Visa requirement as impediment to } \\
\text { visitation }\end{array}$ & 2,4571 & 1,3377 \\
\hline Tourism animation & 2,4000 & 0,8549 \\
\hline
\end{tabular}

Source: Data obtained by survey research 
Table 7. Mean values [AM] and standard deviations [SD] for individual competitiveness indicators of destination management [DESTMNGM]

\begin{tabular}{|c|c|c|}
\hline & Mean & SD \\
\hline Appreciation of service quality importance & 2,5429 & 0,8428 \\
\hline Destination has clear policies in social tourism & 2,1214 & 0,9631 \\
\hline Destination vision reflecting community values & 2,4714 & 0,7722 \\
\hline Destination vision reflecting tourists values & 2,5286 & 0,8262 \\
\hline Destination vision reflecting resident values & 2,4429 & 0,8334 \\
\hline Destination vision reflecting stakeholder values & 2,5786 & 1,0733 \\
\hline Developing and promoting new tourism prodacts & 2,4571 & 0,9397 \\
\hline Development of effective destination branding & 2,3500 & 0,9207 \\
\hline Educational structure/profile of employees in tourism & 2,6714 & 1,8830 \\
\hline Efficiency of tourism/hospitality firms & 2,5071 & 0,9252 \\
\hline Enterpreneurial qualities of local tourism businesses & 2,6929 & 0,8557 \\
\hline Existence of adequate tourism education programs & 2,8000 & 0,9685 \\
\hline Extend of foreign investment in destination tourism industry & 2,1357 & 1,0122 \\
\hline Government co-operation in development of tourism policy & 2,1929 & 0,9205 \\
\hline Level of co-operation between firms & 2,5786 & 0,8981 \\
\hline NTO reputation & 2,4286 & 1,0603 \\
\hline Private sector commitment to tourism/hospitality education & 2,4500 & 0,8759 \\
\hline Private sector recognition of importance of sustainable tourism development & 2,4214 & 0,9526 \\
\hline Public sector commitment to tourism/hospitality education & 2,5571 & 0,9765 \\
\hline Public sector recognition of importance of sustainable tourism development & 2,4214 & 0,9140 \\
\hline Quality in performing tourism services & 2,6071 & 0,8871 \\
\hline Quality of research input to tourism policy, planning, development & 2,3786 & 0,9556 \\
\hline Resident support for tourism development & 2,6571 & 0,9579 \\
\hline Tourism development integrated with overall industry development & 2,3786 & 0,9631 \\
\hline Tourism/hospitality training responsive to visitors needs & 2,4286 & 0,8987 \\
\hline
\end{tabular}

Source: Data obtained by survey research

Table 8. Mean values [AM] and standard deviations [SD] for individual indicators of situational conditions [SITCON]

\begin{tabular}{|l|r|r|}
\hline & \multicolumn{1}{|c|}{ Mean } & \multicolumn{1}{l|}{ SD } \\
\hline Access to venture capital & 2,2429 & 0,8639 \\
\hline $\begin{array}{l}\text { Co-operation between public } \\
\text { and private sector }\end{array}$ & 2,3286 & 0,7906 \\
\hline Investment environment & 2,4071 & 0,9956 \\
\hline Manageres capabilitie & 2,6929 & 0,9283 \\
\hline Political stability & 2,4500 & 1,0201 \\
\hline Securety/safety of visitors & 2,8643 & 0,9384 \\
\hline Use of e-commerce & 2,7071 & 0,9095 \\
\hline Use of IT by firms & 2,7071 & 1,0071 \\
\hline Value for money in accomodation & 2,7500 & 0,8986 \\
\hline Value for money in shopping items & 3,0429 & 0,9125 \\
\hline $\begin{array}{l}\text { Value for money } \\
\text { in tourism destination experience }\end{array}$ & 2,7500 & 0,8576 \\
\hline
\end{tabular}

Source: Data obtained by survey research
Access to venture capital (AM=2,2429; $\mathrm{SD}=0,8639)$, cooperation between public and private sector, investment environment and political stability are the least competitive comparing to Serbian competitors. A low standard deviation for the cooperation between private and public sector $(\mathrm{SD}=0,7906)$ indicates a high level of agreement in respondents opinion while rating this indicator (Table 8).

\section{Demand conditions}

Positive images of destinations help decision makers to construct an "awareness" and "evoked" sets that can thus serve as differentiating factors among competing destinations (De Jager, 20Io). Destination image affects tourist's subjective perception, consequent behaviour and destination choice (Woodside, Lysonski, I989; Baloglu, McCleary, I999; Castro et al, 2007; Chon, I990; Echtner, Ritchie, I99I; Milman, Pizam, I995). In addition, destination image exercises a positive influence on the perceived quality and satisfac- 
tion (Sæbórsdóttir, 20Io). More favourable image will lead to a higher tourist satisfaction. In turn, the evaluation of the destination experience will influence the image and modify it (Chon, I99I; Echtner, Ritchie, I99I; Fakeye, Crompton, I99I; Ross, 1993) which is of an utmost importance for Serbian touristic development. According to the applied model, demand conditions are those concerning destination's international awareness and image.

Serbia is less competitive in all of the integrated model demand condition indicators compared to those of the competitors (Table 9). Each of these items is important for generating high and stable tourism flows in the future. The lowest rating given to international awareness should alarm tourism stakeholders.

\section{Relation between the main competitiveness determinants}

In order to study the relations between the main competitiveness elements, mean values were calculated for each of the competitiveness categories from the individual competitive statements in each category (methodology adopted from Omerzel- Gomezelj, Mihalic, 2008). Main competitiveness elements are presented in Figure I: Inherited (INHRES), Created (CRERES) and Supporting Resources (SUPRES), Destination Management (DESTMNGM), Situational conditions (SITCON), Demand conditions (DEMANCON).

Than in order to check whether there is a statistical significance among the grouped factors, the analysis of pared samples t-tests was conducted.

The results in Table ro indicate statistically significant differences between variables in all cases referring to the main hypothesis and sub-hypotheses. However, the main hypothesis and sub-hypotheses were not completely proven. Ac-
Table 9. Mean values [AM] and standard deviations [SD] for individual competitiveness indicators of demand conditions [DEMANDCON]

\begin{tabular}{|l|r|c|}
\hline & Mean & \multicolumn{1}{c|}{ SD } \\
\hline $\begin{array}{l}\text { "Fit" between destination products and } \\
\text { tourists preferences }\end{array}$ & 2,4714 & 0,8434 \\
\hline $\begin{array}{l}\text { International awareness } \\
\text { of destination products }\end{array}$ & 2,3357 & 0,9338 \\
\hline Overall destination image & 2,2786 & 0,9526 \\
\hline International awareness of destination & 2,2357 & 0,9566 \\
\hline
\end{tabular}

Source: Data obtained by survey research

cording to Serbian tourism experts, Serbia is more competitive in its Resources than in Destination Management, especially concerning its natural resources (INHRES). On the other hand, Inherited and Supporting resources are less competitive than Destination Management. Additionally, a first sub-hypothesis was statistically proven: among resources, inherited resources are more competitive than the created resources and are at the same time more competitive than supporting resources.

Regarding the second sub-hypothesis, situational conditions in the destination are considered, by travel experts, more competitive than Destination management, and this was statistically proven as well.

However, comparing Destination management and Demand conditions, it turned out that Demand conditions are less competitive than Destination management, meaning that main hypothesis and third sub-hypothesis were not proven. Consequently it can be concluded that Demand conditions are the weakest point of Serbian competitiveness. This means that demand conditions referring to the awareness and the image of a destination, have to be improved in order to raise tourism industry competitiveness.

Table 10. Results of competitiveness hypothesis testing-paired sample t-tests

\begin{tabular}{|c|c|c|c|c|c|c|c|}
\hline & \multicolumn{4}{|c|}{ Paired Differences } & \multirow[b]{3}{*}{$t$} & \multirow[b]{3}{*}{ Sig. [2-tailed] } \\
\hline & & \multirow[b]{2}{*}{ Mean } & \multirow[b]{2}{*}{ Std. Deviation } & \multicolumn{2}{|c|}{$\begin{array}{l}\text { 95\% Confidence Interval of the } \\
\text { Difference }\end{array}$} & & \\
\hline & & & & Lower & Upper & & \\
\hline 1. & RESOURSES-DESTMNG & 0,5889 & 0,4026 & 0,5214 & 0,6564 & 17,247 & 0,000 \\
\hline 1.1. & INHRES-DESTMNG & 0,9608 & 0,7080 & 0,8425 & 1,0791 & 16,057 & 0,000 \\
\hline 1.2. & CRERES-DESTMNG & 0,5530 & 0,4200 & 0,4825 & 0,6234 & 15,522 & 0,000 \\
\hline 1.3. & SUPRES-DESTMNG & 0,2555 & 0,4374 & 0,1824 & 0,3285 & 6,911 & 0,000 \\
\hline 1.4. & INHRES-CRERES & 0,4052 & 0,7054 & 0,2869 & 0,5235 & 6,773 & 0,000 \\
\hline 1.5. & INHRES-SUPRES & 0,7053 & 0,6885 & 0,5903 & 0,8204 & 12,122 & 0,000 \\
\hline 2. & CONDITIONS-DESTMNG & & & & & & \\
\hline 2.1. & SITCON-DESTMNG & 0,1563 & 0,3638 & 0,0955 & 0,2171 & 5,083 & 0,000 \\
\hline 2.2. & DEMANDCON-DESTMNG & $-0,1445$ & 0,4890 & $-0,2262$ & $-0,0627$ & $-3,496$ & 0,001 \\
\hline
\end{tabular}

Source: Data obtained by survey research 


\section{Conclusion}

Continuous development of new tourist destinations and the growth of the existing ones impose the need for continuous and responsible destination management in order to achieve and maintain an appropriate level of competitiveness. To think of Serbia as a tourist destination firstly requires understanding the factors that influence competitiveness as well as their analysis and empirical application in order to measure the advantages and disadvantages of Serbian tourism and determine its real competitive position in the world tourist market. Thus, the aim of this study was to determine the weakest point of Serbian tourism competitiveness by applying the Integrated model of competitiveness. In the light of these results, we could state that natural and created resources of the destination are necessary for tourism development, but are not the only and key drivers of destination tourism development.

Therefore, achieving a good performance and position in the tourism market depends on the capability of a destination area to manage and organise its resources according to the economic logic driven by competitive strategies (Cracolici, Nijkamp, 2009). Competitive strategies should be aimed at increasing the competitiveness of the weakest elements of Serbian tourism, which are, as research shows, demand conditions and destination management. What could be find interested is the fact that Slovenian researchers who applied the same Integrated model of destination competitiveness gain almost the same results. The main hypothesis which claims that the destination management is the least competitive was not proven. It turns out in both cases for Slovenia and Serbia that demand condition is concern to be the least competitive. However, while Serbian respondents perceived inherited resources as the most competitive, Slovenian respondents perceived situational conditions as the most competitive elements of their destination. Thus, it is recommended for further research to investigate the possible reasons for the similarities gained in the researches of Slovenia and Serbia.

But in order to upgrade their competitive position both countries must improve their demand conditions which according to the Integrated model, consist of destination image, the existence of awareness of the destination on the international market and "fit" between destination products and tourism preferences.

Low competitivness of demand conditions could be a consequence of low qoverment involvment and support to the planned development of the destination, so the marketing effort doesn't work in the desired direction. The very low rating given to international awareness should alarm tourism stakeholders and stronger promotional activities on the international market are required.

Secondly, improvement should be made in the cooperation between public and private sector. A strong spirit of partnership and collaboration is required among all stakeholders to realise the potential of the destination, to maximise available resources and effects of their marketing activities.

Third, government co-operation in the development of tourism policy is not satisfactory. Ensuring an appropriate and dynamic organisational structure to manage the destination tourism process is a vital element of the destination competitiveness. Government should be involved in the promotion, regulation, presentation, planning, monitoring, co-ordination and organisation of tourism resources.

Finally, destination management should, through adequate management of natural and created resources, provide the basis for differentiation from competitive countries. Destinations have to face the challenge of managing and organising their resources efficiently in order to supply a holiday experience that must outperform alternative destination experiences.

\section{References}

Alavi, J., Yasin, M. M. 2000. A systematic approach to tourism policy. Journal of Business Research, 48(2), I47-I56.

Armenski, T., Zakic, L., Dragin, A. 2009. Percepcija inostranih turista o imidzu Srbije. Glasnik Srpskog geografskog drustva, 89 (I), 39-63.

Baloglu S, McCleary K. W. I999. A model of destination image formation. Annals of Tourism Research 26 (4), 868-897.

Besermenji, S., Pivac, T., Wallrabenstein, K. 2009. Significance of the authentic ambience of the Petrovaradin fortress on the attractiveness of Exit festival. Geographica Pannonica, I3 (2), 6674 .

Besermenji, S., Pivac, T., Wallrabenstein, K. 20 Io. Attitudes of experts from Novi Sad on the use of the authentic setting of the Petrovaradin fortress as the venue for the Exit festival. Geographica Pannonica, I4 (3), 92-97.

Castro C. B, Armario E. M, Ruiz D. M. 2007. The influence of market heterogeneity on the relationship between a destination's image and tourists' future behaviour. Tourism Management 28 (I), I75-I87.

Cho, D.S. I998. From national competitiveness to bloc and global competitiveness. Competitiveness Review, 8(I). 
Chon K. S. I990. The role of destination image in tourism: A review and discussion. Tourist Review 45 (2), 2-9.

Chon K. S. I99I. Tourism destination image modification process. Tourism Management I2 (I), 6872.

Cracolici, M., F., Nijkamp, P. 2009. The attractiveness and competitiveness of tourist destinations: A study of Southern Italian regions. Tourism Management, 30 (3), 336-344.

Crouch G., Ritchie, J.R.B. I995. Destination competitiveness and the role of the tourism enterprise. In Proceedings of the Fourth Annual Business Congress, Istanbul, Turkey, July I3-I6 (pp. 43-48).

Crouch, G., Ritchie, J.R.B. I994. Destination competitiveness: Exploring foundations for a longterm research program. In Proceedings of the Administrative Sciences Association of Canada Annual Conference, Halifax, Nova Scotia, June 25-28, 1994 (pp. 79-88).

Crouch, G.I., Ritchie, J.R.B. I999. Tourism, competitiveness, and societal prosperity. Journal of Business Research, 44, I37-I52.

De Jager, A. 20Io. How Dull is Dullstroom? Exploring the Tourism Destination Image of Dullstroom. Tourism Geographies, I2(3), 349-370.

De Keyser, R., Vanhove, N. I994. The competitive situation of tourism in the Caribbean areaMethodological approach. Revue de Tourisme, 3, I9-22.

Dragin A.S, Dragin V, Plavsa J, Ivkov A, Djurdjev B.S. 2007. Cruise Ship Tourism on the Danube in Vojvodina Province as a Segment of Global Tourism. Geographica Pannonica II, 59-64.

Dwyer, L., Forsyth, P., Rao, P. I999. Tourism price competitiveness and journey purpose. Turizam (Special issue on Competitiveness in Tourism and Hospitality), (47) 4, 283-299.

Dwyer, L., Forsyth, P., Rao, P. 200oa. The price competitiveness of travel and tourism: a comparison of I9 destinations. Tourism Management 2I(I), 9-22.

Dwyer, L., Forsyth, P., Rao, P. 2ooob. Sectoral analysis of price competitiveness of tourism: An international comparison. Tourism Analysis 5(I), I-I2.

Dwyer, L., Forsyth, P., Rao, P. 2002. Destination price competitiveness: Exchange rate changes vs inflation rates. Journal of Travel Research 40(3), 328-336.

Dwyer, L., Kim, C. 2003. Destination competitiveness: Determinants and indicators. Current Issues in Tourism 6, 369-4I4, Routledge, London.

Dwyer, L., Livaic, Z., Mellor, R. 2003. Competitiveness of Australia as a tourist destination. Journal of Hospitality and Tourism Management Io, 6o-78, Sage Publications, London.
Echtner C. M, Ritchie J. R. B. I99I. The meaning and measurement of destination image. The Journal of Tourism Studies 2 (2), 2-I2.

Enright, M. J, Newton J. 2004. Tourism destination competitiveness: a quantitative approach. Tourism Management 25 (6), 777-788.

Evans, M. R., Johnson R. B. I995. Identifying competitive strategies for successful tourism destination development. Journal of Hospitality and Leisure Marketing 3I, 37-45.

Fakeye, P. C., Crompton J. L. I99I. Image Differences between Prospective, First-Time, and Repeat Visitors to the Lower Rio Grande Valley. Journal of Travel Research 30 (2),IO-I6.

Hassan, S. S. 200o. Determinants of market competitiveness in an environmentally sustainable tourism industry. Journal of Travel Research 38 (3), 239-245.

Horwath Consulting Zagreb, Economic Faculty Belgrade. 2005. Strategy of Tourism Development, in Serbian.

Howard, L.H., Allen, D. 2008. Visitor and Nonvisitor Images of Central and Eastern Europe: a Qualitative Analysis. International Journal of Tourism Research Io (I), 27-40.

Ivkov, A., Kovacevic, T., Dragin, A., Djurdjev, B., Ivanovic, Lj. 2007. Influence of tourism on the employment in Vojvodina. Geographica Pannonica II, 54-58.

Ivkov-Dzigurski, A., Kovacevic, T., Zakic, L. 2008. Suveniri kao deo kulturnog nasleđa stanovnistva u funkciji turistickog proizvoda. Glasnik srpskog geografskog drustva 88 (4), 59-69.

Jovicic, D. 2008. State and perspectives of spa tourism development in Serbia. Glasnik srpskog geografskog drustva 88 (4), 3-I8.

Kim, C., Dwyer, L. 2003. Destination competitiveness and bilateral tourism flows between Australia and Korea. Journal of Tourism Studies I4(2), 55-67.

Kotler, P. 2006. Marketing Management. Prentice Hall International. London, 790.

Kozak, M. 20oI. Repeaters' behavior at two distinct destinations. Annals of Tourism Research 28 (3), 784-807.

Kozak, M., Rimmington, M. I999. Measuring tourist destination competitiveness: Conceptual considerations and empirical findings. International Journal of Hospitality Management I8(3), 273-284.

Mihalic, T. 20oo. Environmental management of a tourist destination A factor of tourism competitiveness. Tourism Management 2I(I), 65-78.

Milman A, Pizam A. I995. The role of awareness and familiarity with a destination: The central Florida case. Journal of Travel Research 33 (3), 2I27. 
Moon, H.C., Peery, N. I995. Competitiveness of product, firm, industry, and nation in a global business. Competitiveness Review 5(I), 37-43.

Narashima, S. 2000. Organisation knowledge, human resource management, and sustained competitive advantage: Toward a framework. Competitiveness Review Io(I), I23-I35.

Omerzel- Gomezelj, D., Mihalic, T. 20o8. Destination competitiveness-Applying different models, the case of Slovenia. Tourism Management 29 (2), 294-307.

Pearce, D.G. I997. Competitive destination analysis in southeast Asia. Journal of Travel Research 35(4), I6-25.

Porter, M. I990. The competitive advantage of nations. New York: The Free Press.

Popesku, J. 20o8. Osnove procesa upravljanja turistickom destinacijom. Beograd: Fakultet za turisticki i hotelijerski menadzment, Univerzitet Singidunum. 264 pp.

Ritchie, B. J. R., Crouch, G. I. I993. Competitiveness in international tourism-a framework for understanding and analysis. Reports on 43rd Congress, 35, 23-7I.

Ritchie, J. R. B., Crouch, G. I. 200o. The competitive destination, a sustainable perspective. Tourism Management 2I(I), I-7.

Ritchie, J. R. B., Crouch, G. I. 2003. The competitive destination, a sustainable tourism perspective. Cambridge: Cabi Publishing.

Ross, G. F. 1993. Destination evaluation and vacation preferences. Annals of Tourism Research 20, 477-489.
Ruhanen, L. 2007. Destination competitiveness. In A. Matias, P. Nijkamp, P. Neto (Eds.), Advances in modern tourism research (pp. I33I52). Heidelberg: Physika- Verlag.

Sæpórsdóttir, D. Anna. 20I0. Planning Nature Tourism in Iceland based on Tourist Attitudes. Tourism Geographies I2(I), 25- 52.

Statistical office of Republic of Serbia, 2010. (downloaded from: http://webrzs.stat.gov.rs/ WebSite/Default.aspx)

Statistical office of Republic of Serbia:

Stetic, S., Simicevic, D. 2008. How to Develop Rural Tourism in Serbia. Glasnik srpskog geografskog drustva 88(4), I9-28.

Stojanovic, V., Stamenkovic, I. 20o8. Geoturizam u strukturi savremenih turistickih kretanja. Glasnik srpskog geografskog drustva 88(4), 53-58.

Teece, D. J., Pisano, G., Shuen, A. I997. Dynamic capabilities and strategic management. Strategic Management Journal I8(7), 509-533.

Thomas, R., Long, J. 2000. Improving competitiveness: Critical success factors for tourism development. Journal of the London Economic Policy Unit 4, 313-328.

Waheeduzzan, A., Ryans, J. I996. Definition, perspectives, and Understanding of international competitiveness: A quest for a common ground. Competitiveness Review 6(2), 7-26.

Woodside, A. G, Lysonski S. I989. A general model of traveller destination choice. Journal of Travel Research 27(4), 8-I4. 